\title{
ACCURACY ASSESSMENT OF LANDSAT-DERIVED CONTINUOUS FIELDS OF TREE COVER PRODUCTS USING AIRBORNE LIDAR DATA IN THE EASTERN UNITED STATES
}

\author{
X. P. Song ${ }^{\text {a, } *, H . ~ T a n g ~}{ }^{\text {a }}$ \\ a Department of Geographical Sciences, University of Maryland, College Park, Maryland, United States - (xpsong, htang)@umd.edu
}

KEY WORDS: Land Cover, Tree Cover, Landsat, Lidar, Accuracy

\begin{abstract}
:
Knowing the detailed error structure of a land cover map is crucial for area estimation. Facilitated by the opening of the Landsat archive, global land cover mapping at 30-m resolution has become possible in recent years. Two global Landsat-based continuous fields of tree cover maps have been generated by Sexton et al. (2013) and Hansen et al. (2013) but the accuracy of which have not been comprehensively evaluated. Here we used canopy cover derived from airborne small-footprint Lidar data as a reference to evaluate the accuracy of these two datasets as well as the National Land Cover Database 2001 canopy cover layer (Homer et al. 2004) in two entire counties in Maryland, United States. Our results showed that all three Landsat datasets captured well the spatial variations of tree cover in the study area with an $r^{2}$ ranging between 0.54 and 0.58 , a mean bias error ranging between $-15 \%$ and $5 \%$ tree cover, and a root mean square error ranging between $27 \%$ and $29 \%$ tree cover. When the continuous tree cover maps were converted to binary forest/nonforest maps, all three products were proved to have an overall accuracy $>=80 \%$ but with significant differences in producer's accuracy and user's accuracy. Data users are thus suggested to beware of these accuracy patterns when selecting the most appropriate dataset for their specific applications.
\end{abstract}

\section{INTRODUCTION}

Changes in forest cover significantly affect the global carbon cycle, the hydrological cycle and biodiversity richness (Foley et al., 2005). Satellite observations, owing to their synoptic and repetitive nature, are commonly used for characterizing forest cover and monitoring forest cover change, especially in remote regions. Among various types of satellite data, optical imagery is often the primary data source for characterizing forest cover and detecting forest cover change owing to its large data availability. In particular, the Landsat series of satellite have been providing consistent moderate spatial resolution data since 1972. Recent opening of the Landsat archive and distribution of standardized radiometric images by the United States Geological Survey (USGS) have ignited the use of Landsat data in a wide range of scientific applications, including global land cover mapping at 30-m resolution (Wulder et al., 2012).

Global land cover mapping has been historically relying on coarse spatial resolution data. Since the generation of the first satellite-based land cover product debuted in the mid-1990s (Defries and Townshend, 1994), many global land cover maps have been produced at resolutions from $300-\mathrm{m}$ to $1-\mathrm{km}$ (Bartholomé and Belward, 2005; Bicheron et al., 2008; Friedl et al., 2002; Hansen et al., 2000; Loveland et al., 2000). The proliferation of available datasets provides users rich alternatives yet simultaneously creates some confusion as to which data to choose for their specific applications. This confusion is mainly caused by the lack of a comprehensive accuracy assessment of each available product. Many datasets have simply not been comprehensively evaluated. For those validated maps, the accuracy numbers are often generated using diverse reference data and thus are not directly comparable (Fritz and See, 2008; Pflugmacher et al., 2011; Zhao et al., 2014). Many studies have been conducted on comparing different products to identify the relative strength and weakness of each one and in rare cases integrating different datasets for an improved land cover characterization (Jung et al., 2006; Schepaschenko et al., 2015; Song et al., 2014a). However, absolute error estimation of a land cover map is still and always needed because accuracy information is a crucial input for subsequent applications, such as area and associated uncertainty estimation and land cover change detection (Olofsson et al., 2013; Sexton et al., 2015; Song et al., 2014b).

The last few years have witnessed the production of global land cover maps at 30-m spatial resolution using Landsat data (Chen et al., 2014; Gong et al., 2013; Townshend et al., 2012). Two global, Landsat-derived continuous fields of tree cover products have been generated for free public access (Hansen et al., 2013; Sexton et al., 2013). The spatial details revealed by these Landsat-based products are 100-1000 times more than those coarse-resolution maps. However, users may still face the same choice confusion as with their coarse-resolution counterparts because neither product has been comprehensively validated (Pengra et al., 2015), even though Sexton et al. (2013) applied error estimation of their map in four selected forest sites. Till now, no direct comparison analysis which may inform users on the agreement and discrepancy of the two datasets has been conducted yet.

The availability of high-quality reference data is a major constraint to global land cover validation (Strahler et al., 2006). Reference data can be collected from ground surveys, which are often unavailable because of the associated high economic cost. They can also be derived from higher-resolution imagery or other data sources which depict land cover reliably. A conceptually different and potentially more reliable way of characterizing tree cover is using light detection and ranging (Lidar) data. Lidar is a newly developed active remote sensing technology. It can

\footnotetext{
* Corresponding author
} 
accurately determine the actual position of objects in threedimensional space by counting the roundtrip time of emitted laser between sensor and target (Lefsky et al., 2002). The laser is typically operated at a wavelength of either green or near-infrared range with very fine resolution footprint $(0.5 \mathrm{~m}$ or less $)$ and high scanning frequency (typically $50 \mathrm{khz}$ to $100 \mathrm{khz}$ ) in studies of terrestrial ecology. The high density of Lidar scanning shots can depict detailed structure of forest and thus allows a highly accurate virtual re-construction of individual trees (Dubayah and Drake, 2000). Such advantage makes Lidar a powerful and popular tool in measurements of different forest attributes, including canopy height, aboveground biomass, leaf area index, as well as canopy cover (Falkowski et al., 2008; Korhonen et al., 2011; Lovell et al., 2003; Morsdorf et al., 2006; Tang et al., 2014; Tang et al., 2012).

The objective of this paper is to demonstrate the applicability of airborne Lidar data as reference to evaluate land cover products generated from optical satellite data. Two unique advantages of small-footprint Lidar allow itself to be an excellent reference data: (1) a high spatial resolution and (2) an explicit characterization of canopy height as well as canopy cover. Here we use wall-to-wall Lidar-derived canopy cover above $2.5-\mathrm{m}$ height to evaluate the accuracy of three Landsat-based continuous fields of tree cover maps in the eastern United Sates.

\section{MATERIALS AND METHODS}

\subsection{Study Area}

The study area encompasses two counties-Howard County and Anne Arundel County in the State of Maryland, United Sates (Figure 1). Bordering the Chesapeake Bay, the study area has a seasonal climate and flat terrains. Located in the corridor of two metropolises-Washington D.C. and Baltimore, it has a typical North American suburban landscape consisting of residential lands, agricultural fields, and fragmented forests. Large patches of forest are mainly located in state and local park reserves, largely dominated by broad-leaf deciduous trees mixed with some needle-leaf evergreen trees. As a well-developed region, land cover change in this area is relatively rare and mainly in the form of housing development on forested or agricultural lands.

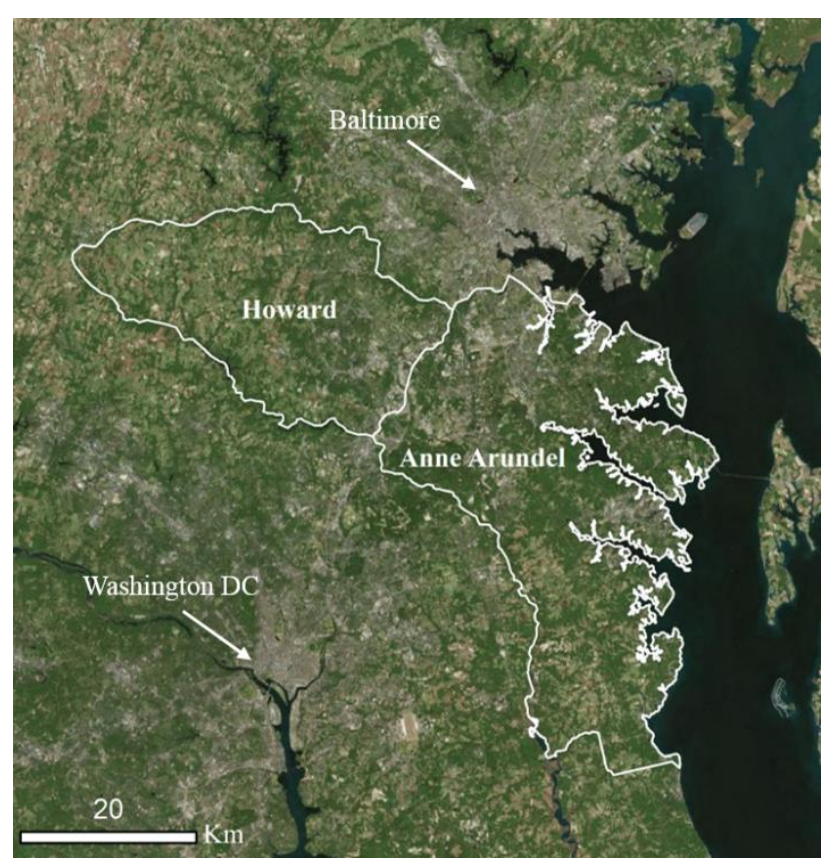

Figure 1. Study area.

\subsection{Landsat-derived continuous fields of tree cover maps}

Three Landsat-derived vegetation continuous fields (VCF) of tree cover products were evaluated in this study. The first dataset (hereafter referred as DS1) was developed by Sexton et al. (2013). The basic input data were Landsat Thematic Mapper (TM) and Enhanced Thematic Mapper Plus (ETM+) images from the Global Land Survey (GLS) collection circa 2000 (Gutman et al., 2013). Leaf-off images were replaced with leaf-on images selected from the USGS Landsat archive based on phenological information from the Moderate Resolution Imaging Spectroradiometer (MODIS) (Channan et al., 2015). All images were converted to surface reflectance (SR) using the Landsat Ecosystem Disturbance Adaptive Processing System (LEDAPS) (Masek et al., 2006). Water, cloud and shadow pixels were identified using methods reported in Huang et al. (2008) and Huang et al. (2010). 30-m Landsat SR data were first spatially aggregated to $250-\mathrm{m}$ resolution. Regression tree models were trained for each Landsat Worldwide Reference System (WRS)-2 tile using reference data derived from spatiotemporally collocated 250-m MODIS VCF product and then applied to 30$\mathrm{m}$ Landsat SR to predict percent tree canopy cover per pixel. This dataset is available at http://glcf.umd.edu/data/landsatTreecover/.

The second dataset (hereafter referred as DS2) was developed by Hansen et al. (2013). The basic input data were all Landsat ETM+ images of year 2000 in the USGS archive. Landsat data were converted to top-of-atmosphere (TOA) reflectance, normalized to surface reflectance according to MODIS SR, and corrected for surface anisotropy (Hansen et al., 2008; Potapov et al., 2012). After screening cloud, shadow and water, a per-pixel composition was carried out to create a series of phonological metrics (Hansen et al., 2013; Potapov et al., 2015). Regression tree models were trained using reference data derived from highresolution imagery and then applied to Landsat metrics to predict percent tree canopy cover per pixel. This dataset is available at http://earthenginepartners.appspot.com/science-2013-globalforest/download_v1.1.html.

The third dataset (hereafter referred as DS3) was the National Land Cover Database 2001 (NLCD2001) tree canopy cover layer developed by Homer et al. (2004). Advanced Very High Resolution Radiometer (AVHRR)-derived Normalized Difference Vegetation Index (NDVI) was used to select Landsat TM or ETM+ images acquired in early, peak and late of vegetation growing seasons. Selected Landsat images were converted to at-satellite reflectance for the six reflective bands and to at-satellite temperature for the thermal band and subsequently transformed to brightness, greenness and wetness indices through a Tasseled Cap Transformation (Huang et al., 2002; Kauth and Thomas, 1976). Similar to the other two global products, regression tree classifiers were trained using reference data obtained from aerial photographs, field-work as well as the Forest Inventory Analysis (FIA) database and applied to multiseason Landsat image triplets to predict percent tree canopy cover per $30-\mathrm{m}$ pixel. This dataset is available at http://www.mrlc.gov/nlcd01_data.php.

\subsection{Reference tree canopy cover derived from Lidar}

The Lidar data were obtained from the Maryland Department of Natural Resources in primary support of shore erosion studies along the Chesapeake Bay. They were later made available in support of the National Aeronautics and Space Administration (NASA) Carbon Monitoring System (CMS) projects. The original Lidar point cloud was collected from April to May 2004 
over two entire counties of Maryland (Anne Arundel and Howard). Canopy cover was calculated as the percentage of Lidar points above $2.5-\mathrm{m}$ height in total Lidar points within each $30-\mathrm{m}$ grid. Lidar point cloud data were also processed to derive digital elevation model (DEM) and canopy height model (DSM) at 2-m spatial resolution.

\subsection{Evaluation metrics}

The accuracy of the Landsat-based continuous tree cover was evaluated against Lidar-derived percent canopy cover using four metrics: mean bias error (MBE), mean absolute error (MAE), root mean square error (RMSE) and $\mathrm{r}^{2}$ (Willmott, 1982):

$$
\begin{aligned}
& M B E=\frac{\sum_{i=1}^{n}\left(t c_{i}-r_{i}\right)}{n} \\
& M A E=\frac{\sum_{i=1}^{n}\left|t c_{i}-r_{i}\right|}{n} \\
& R M S E=\sqrt{\frac{\sum_{i=1}^{n}\left(t c_{i}-r_{i}\right)^{2}}{n}} \\
& r^{2}=1-\frac{\sum_{i=1}^{n}\left(t c_{i}-r_{i}\right)^{2}}{\sum_{i=1}^{n}\left(t c_{i}-\bar{r}\right)^{2}}
\end{aligned}
$$

where $\quad i=$ pixel index

$t c_{i}=$ percent tree cover of each product $r_{i}=$ reference percent tree cover from Lidar $\bar{r}=$ mean of reference percent tree cover $n=$ sample size

In addition to the above continuous error metrics, we also converted the continuous tree cover maps to discrete forest/nonforest classification maps and constructed traditional confusion matrixes for each classification product. Following the International Geosphere-Biosphere Programme (IGBP) definition of open forest, a 30\% tree cover threshold was applied to categorize tree cover pixels into either forest or nonforest class (Belward, 1996). Producer's accuracy (1 - omission error), user's accuracy (1 - commission error) and overall accuracy for both classes were then summarized from the confusion matrixes for each product.

\section{RESULTS AND DISCUSSION}

\subsection{Qualitative Assessment}

All three products depict well the spatial variations of tree cover over the study area (Figure 2). Dense tree cover patches of riparian forests and the Patuxent Research Refuge (center of the study area) are clearly shown on all maps. A close visual examination concludes that DS1 underestimates high-end tree cover (i.e. less pixels with high tree cover than the reference), DS2 overestimates high-end tree cover, whereas DS3 overestimates low-end tree cover.

The frequency distributions of tree cover from the four datasets confirm the conclusions drawn from the visual examination (Figure 3). All three datasets show a bimodal distribution. Both DS1 and DS2 have a close agreement with the reference at low canopy cover but DS1 saturates at about $80 \%$ with its peak located at around $60 \%$ canopy cover. The maximum value of DS2 reaches $100 \%$ canopy cover but has significantly more
$100 \%$ tree cover pixels than the reference. The high-end peak of DS3 ( $\sim 90 \%$ canopy cover) has the closest agreement with the reference, but DS3 has significantly more $0 \%$ tree cover pixels than the reference.

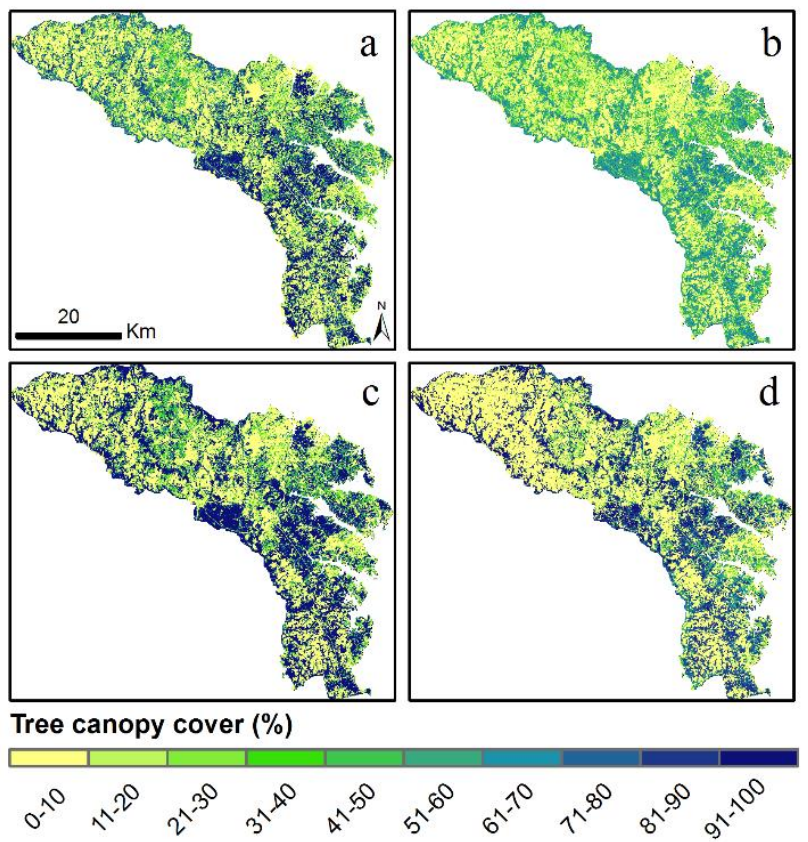

Figure 2. Maps of percent tree canopy cover in Howard County and Anne Arundel County, Maryland. a. Reference data derived from airborne Lidar. b. Landsat-based tree cover DS1 (Sexton et al. 2013). c. Landsat-based tree cover DS2 (Hansen et al. 2013). d. Landsat-based tree cover DS3 (Homer et al. 2004).

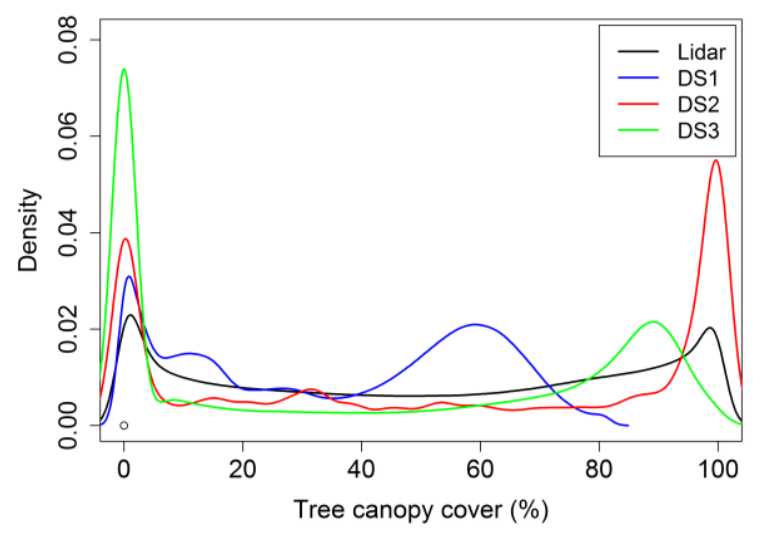

Figure 3. Frequency distributions of percent tree canopy cover in the study area from Lidar reference and three Landsat-based products.

The agreement and disagreement (over- or under-estimation) patterns are more clearly shown on the density scatter plots (Figure 4). Bimodal peaks of low and high tree cover are represented by the two red regions at the lower-left and upperright corners of each figure, respectively. DS1 has a clear overall underestimation across the tree cover spectrum (i.e. most data points are located above the 1:1 line). DS1 also saturates at $81 \%$, a feature inherited from its training data MODIS VCF. DS2 not only has an overall overestimation across the range but also appears to have a discontinuous structure, especially at moderate 
tree cover. DS3 has the least overall bias but misses a significant amount of tree pixels (i.e. mislabelled as $0 \%$ ).

a

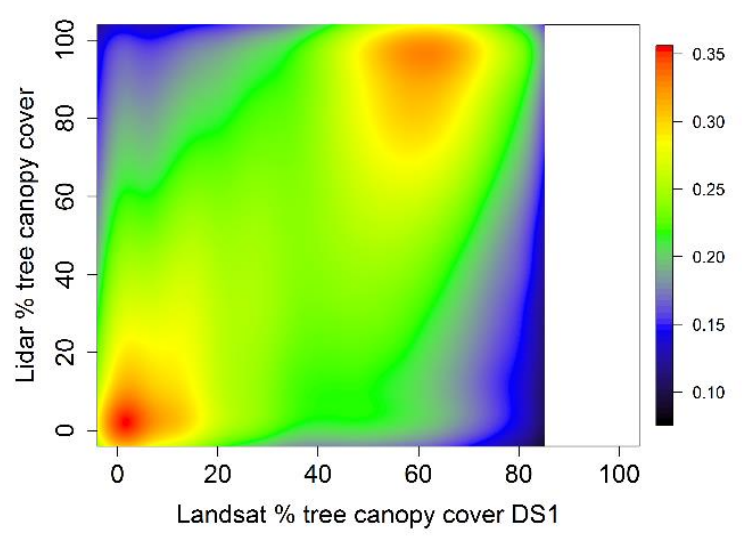

b

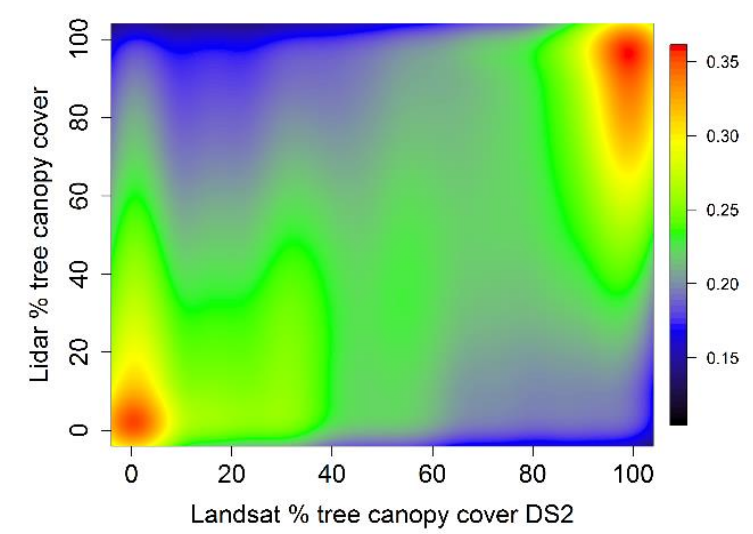

c

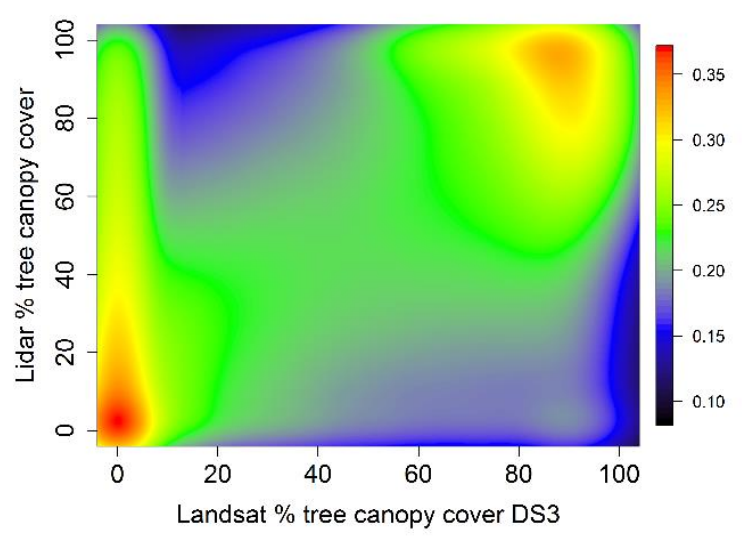

Figure 4. Scatter plots of Landsat-based percent tree canopy cover against Lidar reference. a. DS1 (Sexton et al. 2013). b. DS2 (Hansen et al. 2013). c. DS3 (Homer et al. 2004). Colours in the legends indicate scatter density.

\subsection{Quantitative Assessment of continuous tree cover maps}

Table 1 lists four error metrics calculated for the three datasets. The MBE values suggest that both DS1 and DS3 underestimate canopy cover while DS2 overestimates canopy cover. All three products are comparable in terms of absolute error with MAE ranging between $20 \%$ and $22 \%$ and RMSE ranging between $27 \%$ and $29 \%$. Additionally, both DS1 and DS2 explain 58\% of the variation of tree cover captured by the Lidar reference, while DS3 explains a slightly lower portion (54\%) of the variation.

\begin{tabular}{ccccc}
\hline \multirow{2}{*}{ Product } & \multicolumn{4}{c}{ Metrics } \\
\cline { 2 - 5 } & MBE (\%) & MAE (\%) & RMSE (\%) & $\mathrm{r}^{2}$ \\
\hline DS1 & -15 & 22 & 27 & 0.58 \\
\hline DS2 & 5 & 20 & 27 & 0.58 \\
\hline DS3 & -9 & 20 & 29 & 0.54 \\
\hline
\end{tabular}

Table 1. Error metrics of the three Landsat-based tree cover datasets. The units of MBE, MAE and RMSE are all percent tree canopy cover.

\subsection{Quantitative Assessment of re-classified forest/nonforest maps}

Table 2 lists the overall accuracy (OA), producer's accuracy (PA or 1 - omission error), user's accuracy (UA or 1 - commission error) summarized from the traditional confusion matrixes, which were constructed by categorizing continuous tree cover data into discrete forest $(\mathrm{F})$ /nonforest $(\mathrm{NF})$ classification. DS1 has the highest OA (82\%), followed by DS2 $(81 \%)$ and then by DS3 (80\%). However, DS2 has the highest PA for the forest class (86\%), while DS3 has the highest UA for the forest class (92\%).

\begin{tabular}{cccccc}
\hline \multirow{2}{*}{ Product } & \multirow{2}{*}{ OA } & \multicolumn{2}{c}{ PA } & \multicolumn{2}{c}{ UA } \\
\cline { 3 - 6 } & & F & NF & F & NF \\
\hline DS1 & $82 \%$ & $80 \%$ & $85 \%$ & $91 \%$ & $70 \%$ \\
\hline DS2 & $81 \%$ & $86 \%$ & $73 \%$ & $85 \%$ & $74 \%$ \\
\hline DS3 & $80 \%$ & $75 \%$ & $88 \%$ & $92 \%$ & $65 \%$ \\
\hline
\end{tabular}

Table 2. Summary of accuracy numbers of the re-classified forest/nonforest maps derived from the three Landsat-based continuous tree cover datasets.

\section{CONCLUSIONS}

We have demonstrated the applicability of small-footprint airborne Lidar data as reference to evaluate the accuracy of land cover products generated from optical satellite data. Using wallto-wall Lidar-derived canopy cover as reference, we estimated the accuracy of three Landsat-based continuous fields of tree cover datasets (Sexton et al. 2013; Hansen et al. 2013; Homer et al. 2004) in Howard County and Anne Arundel County, Maryland, USA. The results showed various error patterns of the three percent tree cover datasets, although they were generated from similar input data with similar machine learning algorithms. All three datasets captured well the spatial variations of tree canopy cover with an $r^{2}$ ranging between 0.54 and 0.58 , a mean bias error ranging between $-15 \%$ and $5 \%$, and a root mean square error ranging between $27 \%$ to $29 \%$. When the continuous tree cover maps were converted to binary forest/nonforest maps, all three products were proved to have an overall accuracy $>=80 \%$, 
with various producer's accuracy and user's accuracy for the forest and nonforest classes. Future research will expand the study area to include more study sites in other major forest biomes in the United States.

\section{ACKNOWLEDGEMENTS}

This study was funded by NASA's Earth and Space Science Fellowship (NESSF) Program: NNX12AN92H to Xiao-Peng Song and NNX12AN43H to Hao Tang. We thank the data providers for making their datasets freely available.

\section{REFERENCES}

Bartholomé, E., Belward, A.S., 2005. GLC2000: a new approach to global land cover mapping from Earth observation data. Int. J. Remote Sens. 26, 1959-1977.

Belward, A.S., 1996. The IGBP-DIS global $1 \mathrm{~km}$ land cover data set "DISCover": Proposal and implementation plans, Report of the Land Cover Working Group of IGBP-DIS. IGBP-DIS Office, Toulouse, France.

Bicheron, P., Defourny, P., Brockmann, C., Schouten, L., Vancutsem, C., Huc, M., Bontemps, S., Leroy, M., Achard, F., Herold, M., Ranera, F., Arino, O., 2008. GlobCover: Products Description and Validation Report, Toulouse Cedex, France.

Channan, S., Feng, M., Kim, D.-H., Sexton, J.O., Song, X.-P., Song, D.-X., Noojipady, P., Collins, K., Anand, A., Townshend, J.R., 2015. The GLS+: An Enhancement of the Global Land Survey Datasets. Photogramm. Eng. Remote Sens. 81, 521-525.

Chen, J., Chen, J., Liao, A., Cao, X., Chen, L., Chen, X., He, C., Han, G., Peng, S., Lu, M., Zhang, W., Tong, X., Mills, J., 2014. Global land cover mapping at $30 \mathrm{~m}$ resolution: A POK-based operational approach. ISPRS Journal of Photogrammetry and Remote Sensing.

Defries, R.S., Townshend, J.R.G., 1994. NDVI-Derived LandCover Classifications at a Global-Scale. Int. J. Remote Sens. 15, 3567-3586.

Dubayah, R.O., Drake, J.B., 2000. Lidar remote sensing for forestry. Journal of Forestry 98, 44-46.

Falkowski, M.J., Smith, A.M.S., Gessler, P.E., Hudak, A.T., Vierling, L.A., Evans, J.S., 2008. The influence of conifer forest canopy cover on the accuracy of two individual tree measurement algorithms using lidar data. Canadian Journal of Remote Sensing 34, S338-S350.

Foley, J.A., Defries, R., Asner, G.P., Barford, C., Bonan, G., Carpenter, S.R., Chapin, F.S., Coe, M.T., Daily, G.C., Gibbs, H.K., Helkowski, J.H., Holloway, T., Howard, E.A., Kucharik, C.J., Monfreda, C., Patz, J.A., Prentice, I.C., Ramankutty, N., Snyder, P.K., 2005. Global consequences of land use. Science 309, 570-574.

Friedl, M.A., McIver, D.K., Hodges, J.C.F., Zhang, X.Y., Muchoney, D., Strahler, A.H., Woodcock, C.E., Gopal, S., Schneider, A., Cooper, A., Baccini, A., Gao, F., Schaaf, C., 2002. Global land cover mapping from MODIS: algorithms and early results. Remote Sens. Environ. 83, 287-302.
Fritz, S., See, L., 2008. Identifying and quantifying uncertainty and spatial disagreement in the comparison of Global Land Cover for different applications. Glob. Change Biol. 14, 1057-1075.

Gong, P., Wang, J., Yu, L., Zhao, Y., Zhao, Y., Liang, L., Niu, Z., Huang, X., Fu, H., Liu, S., Li, C., Li, X., Fu, W., Liu, C., Xu, Y., Wang, X., Cheng, Q., Hu, L., Yao, W., Zhang, H., Zhu, P., Zhao, Z., Zhang, H., Zheng, Y., Ji, L., Zhang, Y., Chen, H., Yan, A., Guo, J., Yu, L., Wang, L., Liu, X., Shi, T., Zhu, M., Chen, Y., Yang, G., Tang, P., Xu, B., Giri, C., Clinton, N., Zhu, Z., Chen, J., Chen, J., 2013. Finer resolution observation and monitoring of global land cover: first mapping results with Landsat TM and ETM+ data. Int. J. Remote Sens. 34, 2607-2654.

Gutman, G., Huang, C., Chander, G., Noojipady, P., Masek, J.G., 2013. Assessment of the NASA-USGS Global Land Survey (GLS) datasets. Remote Sens. Environ. 134, 249-265.

Hansen, M.C., DeFries, R.S., Townshend, J.R.G., Sohlberg, R.A., 2000. Global land cover classification at $1 \mathrm{~km}$ spatial resolution using a classification tree approach. Int. J. Remote Sens. 21, 1331-1364.

Hansen, M.C., Potapov, P.V., Moore, R., Hancher, M., Turubanova, S.A., Tyukavina, A., Thau, D., Stehman, S.V., Goetz, S.J., Loveland, T.R., Kommareddy, A., Egorov, A., Chini, L., Justice, C.O., Townshend, J.R.G., 2013. High-resolution global maps of 21 st-centry forest cover change. Science 342 , 850-853.

Hansen, M.C., Roy, D.P., Lindquist, E., Adusei, B., Justice, C.O., Altstatt, A., 2008. A method for integrating MODIS and Landsat data for systematic monitoring of forest cover and change in the Congo Basin. Remote Sens. Environ. 112, 2495-2513.

Homer, C., Huang, C., Yang, L., Wylie, B., Coan, M., 2004. Development of a 2001 National Land-Cover Database for the United States. Photogramm. Eng. Remote Sens. 70, 829-840.

Huang, C., Song, K., Kim, S., Townshend, J.R.G., Davis, P., Masek, J.G., Goward, S.N., 2008. Use of a dark object concept and support vector machines to automate forest cover change analysis. Remote Sens. Environ. 112, 970-985.

Huang, C., Thomas, N., Goward, S.N., Masek, J.G., Zhu, Z., Townshend, J.R.G., Vogelmann, J.E., 2010. Automated masking of cloud and cloud shadow for forest change analysis using Landsat images. Int. J. Remote Sens. 31, 5449-5464.

Huang, C., Wylie, B., Yang, L., Homer, C., Zylstra, G., 2002. Derivation of a tasselled cap transformation based on Landsat 7 at-satellite reflectance. Int. J. Remote Sens. 23, 1741-1748.

Jung, M., Henkel, K., Herold, M., Churkina, G., 2006. Exploiting synergies of global land cover products for carbon cycle modeling. Remote Sens. Environ. 101, 534-553.

Kauth, R.J., Thomas, G., 1976. The tasselled cap--a graphic description of the spectral-temporal development of agricultural crops as seen by Landsat, Proceedings of the Symposium on Machine Processing of Remotely Sensed Data, West Lafayette, Indiana, pp. 41-51.

Korhonen, L., Korpela, I., Heiskanen, J., Maltamo, M., 2011. Airborne discrete-return LIDAR data in the estimation of vertical canopy cover, angular canopy closure and leaf area index. Remote Sens. Environ. 115, 1065-1080. 
Lefsky, M.A., Cohen, W.B., Parker, G.G., Harding, D.J., 2002. Lidar Remote Sensing for Ecosystem Studies. Bioscience 52, 1930 .

Loveland, T.R., Reed, B.C., Brown, J.F., Ohlen, D.O., Zhu, Z., Yang, L., Merchant, J.W., 2000. Development of a global land cover characteristics database and IGBP DISCover from $1 \mathrm{~km}$ AVHRR data. Int. J. Remote Sens. 21, 1303-1330.

Lovell, J.L., Jupp, D.L.B., Culvenor, D.S., Coops, N.C., 2003. Using airborne and ground-based ranging lidar to measure canopy structure in Australian forests. Canadian Journal of Remote Sensing 29, 607-622.

Masek, J.G., Vermote, E.F., Saleous, N.E., Wolfe, R.E., Hall, F.G., Huemmrich, K.F., Gao, F., Kutler, J., Lim, T.-K., 2006. A Landsat Surface Reflectance Dataset for North America, 19902000. IEEE Geosci. Remote Sens. Lett. 3, 68-72.

Morsdorf, F., Kötz, B., Meier, E., Itten, K.I., Allgöwer, B., 2006. Estimation of LAI and fractional cover from small footprint airborne laser scanning data based on gap fraction. Remote Sens. Environ. 104, 50-61.

Olofsson, P., Foody, G.M., Stehman, S.V., Woodcock, C.E., 2013. Making better use of accuracy data in land change studies: Estimating accuracy and area and quantifying uncertainty using stratified estimation. Remote Sens. Environ. 129, 122-131.

Pengra, B., Long, J., Dahal, D., Stehman, S.V., Loveland, T.R., 2015. A global reference database from very high resolution commercial satellite data and methodology for application to Landsat derived $30 \mathrm{~m}$ continuous field tree cover data. Remote Sens. Environ. 165, 234-248.

Pflugmacher, D., Krankina, O.N., Cohen, W.B., Friedl, M.A., Sulla-Menashe, D., Kennedy, R.E., Nelson, P., Loboda, T.V., Kuemmerle, T., Dyukarev, E., Elsakov, V., Kharuk, V.I., 2011. Comparison and assessment of coarse resolution land cover maps for Northern Eurasia. Remote Sens. Environ. 115, 3539-3553.

Potapov, P.V., Turubanova, S.A., Hansen, M.C., Adusei, B., Broich, M., Altstatt, A., Mane, L., Justice, C.O., 2012. Quantifying forest cover loss in Democratic Republic of the Congo, 2000-2010, with Landsat ETM+ data. Remote Sens. Environ. 122, 106-116.

Potapov, P.V., Turubanova, S.A., Tyukavina, A., Krylov, A.M., McCarty, J.L., Radeloff, V.C., Hansen, M.C., 2015. Eastern Europe's forest cover dynamics from 1985 to 2012 quantified from the full Landsat archive. Remote Sens. Environ. 159, 28-43.

Schepaschenko, D., See, L., Lesiv, M., McCallum, I., Fritz, S., Salk, C., Moltchanova, E., Perger, C., Shchepashchenko, M., Shvidenko, A., Kovalevskyi, S., Gilitukha, D., Albrecht, F., Kraxner, F., Bun, A., Maksyutov, S., Sokolov, A., Dürauer, M., Obersteiner, M., Karminov, V., Ontikov, P., 2015. Development of a global hybrid forest mask through the synergy of remote sensing, crowdsourcing and FAO statistics. Remote Sens. Environ. 162, 208-220.

Sexton, J.O., Noojipady, P., Anand, A., Song, X.-P., McMahon, S., Huang, C., Feng, M., Channan, S., Townshend, J.R., 2015. A model for the propagation of uncertainty from continuous estimates of tree cover to categorical forest cover and change. Remote Sens. Environ. 156, 418-425.
Sexton, J.O., Song, X.-P., Feng, M., Noojipady, P., Anand, A., Huang, C., Kim, D.-H., Collins, K.M., Channan, S., DiMiceli, C., Townshend, J.R., 2013. Global, 30-m resolution continuous fields of tree cover: Landsat-based rescaling of MODIS vegetation continuous fields with lidar-based estimates of error. Int. J. Digital Earth 6, 427-448.

Song, X.-P., Huang, C., Feng, M., Sexton, J.O., Channan, S., Townshend, J.R., 2014a. Integrating global land cover products for improved forest cover characterization: an application in North America. Int. J. Digital Earth 7, 709-724.

Song, X.-P., Huang, C., Sexton, J.O., Channan, S., Townshend, J.R., 2014b. Annual Detection of Forest Cover Loss Using Time Series Satellite Measurements of Percent Tree Cover. Remote Sens. 6, 8878-8903.

Strahler, A.H., Boschetti, L., Foody, G.M., Friedl, M.A., Hansen, M.C., Herold, M., Mayaux, P., Morisette, J.T., Stehman, S.V., Woodcock, C.E., 2006. Global land cover validation: recommendations for evaluation and accuracy assessment of global land cover maps. Office for Official Publications of the European Communities, Luxembourg.

Tang, H., Brolly, M., Zhao, F., Strahler, A.H., Schaaf, C.L., Ganguly, S., Zhang, G., Dubayah, R., 2014. Deriving and validating Leaf Area Index (LAI) at multiple spatial scales through lidar remote sensing: A case study in Sierra National Forest, CA. Remote Sens. Environ. 143, 131-141.

Tang, H., Dubayah, R., Swatantran, A., Hofton, M., Sheldon, S., Clark, D.B., Blair, B., 2012. Retrieval of vertical LAI profiles over tropical rain forests using waveform lidar at La Selva, Costa Rica. Remote Sens. Environ. 124, 242-250.

Townshend, J.R., Masek, J.G., Huang, C., Vermote, E.F., Gao, F., Channan, S., Sexton, J.O., Feng, M., Narasimhan, R., Kim, D., Song, K., Song, D., Song, X.-P., Noojipady, P., Tan, B., Hansen, M.C., Li, M., Wolfe, R.E., 2012. Global characterization and monitoring of forest cover using Landsat data: opportunities and challenges. Int. J. Digital Earth 5, 373-397.

Willmott, C.J., 1982. Some Comments on the Evaluation of Model Performance. B. Am. Meteorol. Sci. 63, 1309-1313.

Wulder, M.A., Masek, J.G., Cohen, W.B., Loveland, T.R., Woodcock, C.E., 2012. Opening the archive: How free data has enabled the science and monitoring promise of Landsat. Remote Sens. Environ. 122, 2-10.

Zhao, Y., Gong, P., Yu, L., Hu, L., Li, X., Li, C., Zhang, H., Zheng, Y., Wang, J., Zhao, Y., Cheng, Q., Liu, C., Liu, S., Wang, X., 2014. Towards a common validation sample set for global land-cover mapping. Int. J. Remote Sens. 35, 4795-4814. 